\title{
COMPARATIVE EFFICACY OF LOW LEVEL LASER THERAPY AND PULSED ULTRASOUND IN THE MANAGEMENT OF SECOND - DEGREE CONTUSION
}

\author{
O Ayanniyi, OB Ogunkunle and CE Mbada \\ Department of Physiotherapy, College of Medicine, University of Ibadan, \\ Ibadan, Nigeria
}

Corresponding Author

o Ayanniyi

\begin{abstract}
SUMMARY
Low level LASER therapy (LLLT) and pulsed ultrasound have been shown to relieve pain, promote healing and tissue repair in sport injuries. The objective of this study was to investigate the comparative efficacy of LLLT and pulsed ultrasound in the management of second - degree contusion in sportsmen.
\end{abstract}

This is a 2 group pre-test - post-test quasi experimental study involving 20 sportsmen, ten were in Group A (LLLT) and ten in Group B (PUS). They were aged between 19 and 30 years with the mean age $24.9 \pm 3.28$ years and $27.4 \pm$ 3.75 years for the Group A and Group B respectively. Treatment consisted of six sessions, in a period of 2 weeks. Data collected on each participants included age, weight, height, site of injury, pain intensity, swelling, calf girth and range of motion.

The result of the study revealed decrease in pain for both LLLT and pulsed ultrasound $(\mathrm{p}<0.05)$. There was more significant reduction in pain at the end of the 2 weeks than the 1 st week for both modalities. Both modalities did not produce significant improvement in ROM or swelling over the two weeks period $(\mathrm{P}>0.05)$.

It was concluded that both therapies are equally effective in the management of pain resulting from second - degree contusion in sportsmen.

KEYWORDS: Low level LASER, pulsed ultrasound, second - degree contusions.

\section{INTRODUCTION}

Contusion in sports injuries constitutes about $60-70 \%$ of all the injuries that occur and it is always in conjunction with almost all other injuries (Keene, 1985). Contusion refers to the compression of soft tissues by direct blow or impact sufficient to cause disruption or damage to small capillaries in the tissue (Cyriax, 1982). A contusion or bruise or ecchymosis is a kind of injury, usually caused by blunt impact, in which the capillaries are damaged, allowing blood to seep into the surrounding tissue (Wikipedia,
2006). Minor contusions heal quickly and without taking an athlete out of game (Huston, 1990) but severe contusions can cause deep tissue damage leading to complications like haematoma, pain, compartment syndrome and myositis ossificans which keep the athlete out of sport for months (DeLee et al, 1994, Wikipedia, 2006).

Contusions have been classified according to the severity or extent of tissue damage and functional impairment into first, second and third degree (Rodgen and Cavanagh, 1984). Stone (1994) also classified contusions into mild, moderate or severe. The typical patients are athletes with second - degree contusion who sustain a direct blow to either anterior thigh or calf muscle. Swelling, pain, and decreased ability to bear weight are the clinical features (Jackson and Feagin, 1973).

A second - degree contusion is characterized by increased pain and haemorrhage due to increased area and depth of tissue damage, resulting in mild to moderate limitation in range of motion and muscle function (Rodgen and Cavanagh, 1984).

Management of contusions is centered around pain control, restoring mobility and functional rehabilitation (Larson et al, 2002), Aside the use of rest, cooling, compression and elevation in the management of contusions (Stone, 1994), low level LASER therapy and pulsed ultrasound have been shown to significantly relieve pain through the release of endomorphin, promote healing and tissue repair in sport injuries (Sherk, 1990; Thomson et al, 1991; Sanders, 1984; Dyson and Pond, 1970; Bjordal et al, 2001; Logdberg-Anderssont et al, 1997). However, studies on comparative efficacy of low level LASER therapy (LLLT) and pulsed ultrasound in the management of medical conditions such as contusion, joint injuries, fractures etc are not recent and are scanty. The objective of this study was to investigate and compare the efficacy of low level LASER therapy (LLLT) and pulsed ultrasound in the management of second - degree contusion. 


\section{METHODS \\ Subjects}

This 2 groups pretest - posttest quasi experimental study involved a total of 20 sportsmen. They were divided into two groups (A, LLLT with 10 subjects), and (B, P-US with 10 subjects) using purposive sampling technique. The subjects were aged between 19 and 30 years. The mean ages were $24.9 \pm 3.28$ years and 27.4 \pm 3.75 years for the Group A and Group B respectively. Participants with second - degree contusion at either the quadriceps or calf muscles referred by the sport physician and met the inclusion criteria of having pain, swelling and limitation in range of motion in the related joint (either the hip, knee or ankle) were included in the study. Data were collected on participants' age, weight, height, site of injury, pain intensity, swelling, calf girth and range of motion. Treatment consisted of six sessions, in a period of 2 weeks.

The participants were purposively recruited at the National Stadium, Lagos.

The treatment protocols used included low level LASER therapy for Group A, and pulsed ultrasound therapy for Group B.

\section{Group A: LLLT}

A gymna unit laser device (by EMS Co., China) with light range of $1-500$ milliwatts. The power of A $200 \mathrm{~mW}$ with a beam area of $0.1 \mathrm{~cm}^{2}$ was used for 20 seconds at a point to deliver $40 \mathrm{~J} / \mathrm{cm}^{2}$ for total of 5 minutes, three times a week for 2 weeks. Direct contact method is also used with the LASER head in touch with the skin of participant.

\section{Group B: Ultrasound Treatment}

Ultrasound 700 ITO (ITO, Physio-therapy and rehabilitation Co., Tokyo) with a power consumption of 72VA and out of $0.10-2.00$ $\mathrm{W} / \mathrm{cm}^{2}$ with a frequency of $50-60 \mathrm{~Hz}$ for pulsed ultrasound. This pulsed mode $\left(0.5 \mathrm{~W} / \mathrm{cm}^{2}\right.$ and a frequency of $3 \mathrm{MHz}$ ) was used for 7 minutes daily, three times a week for 2 weeks. Direct contact method is also used with the transducer head of the ultrasound in contact with the skin of participant using coupling medium.

\section{Procedures}

Ethical approval was obtained from the University of Ibadan / University College Hospital, Institutional Review Committee. The consent of the Sport Physician of the National Stadium was also sought towards the referral of only sportsmen with second - degree contusion. Consented participants' height and weight were measured using standard procedures. Their ages, type of sport, type of injury, pain intensity using Visual Analog Scale (VAS), swelling, calf girth and range of motion were recorded.

\section{Analysis}

The data were analyzed through descriptive statistics of mean and standard deviation. Independent t-test was used to compare the symptoms of the participants in each group. One way analysis of variance (ANOVA) was used to compare the variables across participants in each group at baseline, end of first week and end of second week of treatment. Duncan's multiple range test was used for post-hoc analysis. The confidence level was set at $\mathrm{P}<0.05$.

\section{RESULTS}

The mean age, height, and weight of the participants were $24.9 \pm 3.28$ years, $1.797 \pm$ $18.33 \mathrm{~m}$, and $71.4 \pm 9.81 \mathrm{Kg}$ for group $\mathrm{A}$ and 27.4 \pm 3.75 years, $1.72 \pm 12.7 \mathrm{~m}$, and $72.0 \pm 13.74 \mathrm{Kg}$ for group B respectively. The result of the oneway analysis of variance and Duncan's multiple range test post-hoc analysis of participants' pain intensity across treatment period using Visual Analog Scale is presented in Table 1.

The changes in pain intensity rating were calculated for each group at the end of one week of treatment and at the end of two weeks of treatment using the following equations: Pain intensity (1st week) = Pain intensity (before treatment) - Pain intensity (after treatment).

Pain intensity (2nd week) = Pain intensity (before treatment) - Pain intensity (after 2 weeks of treatment).

Table 1: Summary of the one-way analysis of variance and Duncan's multiple range test posthoc analysis of participant's pain intensity across treatment period using Visual Analog Scale.

\begin{tabular}{llllll}
\hline & $\begin{array}{l}\text { Baseline } \\
\mathbf{X} \pm \text { SD }\end{array}$ & $\begin{array}{l}\text { End of week 1 } \\
\mathbf{X} \pm \text { SD }\end{array}$ & $\begin{array}{l}\text { End of week 2 } \\
\mathbf{X} \pm \text { SD }\end{array}$ & F ratio & P value \\
\hline Group A & $7.90 \pm 1.73^{\mathrm{a}}$ & $6.10 \pm 1.29^{\mathrm{b}}$ & $3.90 \pm 0.99^{\mathrm{c}}$ & $21.37^{*}$ & 0.000 \\
Group B & $8.20 \pm 1.75^{\mathrm{a}}$ & $6.70+1.57^{\mathrm{b}}$ & $4.60 \pm 1.07^{\mathrm{c}}$ & $14.69^{*}$ & 0.000 \\
\hline
\end{tabular}

*Indicates significance difference in pain intensity across different time periods ${ }^{\mathrm{a}, \mathrm{b}, \mathrm{c}}$. For a particular variable, mode means with different superscripts are significantly $(\mathrm{P}<0.05)$ different Mode means with same superscripts are not significantly $(\mathrm{P}<0.05)$ different. 
There was more significant reduction in pain at the end of the 2 weeks than the 1 st week for both modalities.

The result of the one-way analysis of variance and Duncan's multiple range test post- hoc analysis of swelling by limb circumference measurements and joint range of motion across treatment period is presented in Table 2 and Table 3 respectively.

Table 2: Summary of the one-way analysis of variance and Duncan's multiple range test post-hoc analysis of swelling by limb circumference measurements across treatment period. (Limb circumference $(\mathbf{c m}))$.

\begin{tabular}{llllll}
\hline & $\begin{array}{l}\text { Baseline } \\
\mathbf{X} \pm \text { SD }\end{array}$ & $\begin{array}{l}\text { End of week 1 } \\
\mathbf{X} \pm \text { SD }\end{array}$ & $\begin{array}{l}\text { End of week 2 } \\
\mathbf{X} \pm \text { SD }\end{array}$ & F ratio & P value \\
\hline Group A & $81.30 \pm 17.59^{\mathrm{a}}$ & $75.90 \pm 16.00^{\mathrm{b}}$ & $69.10 \pm 13.55^{\mathrm{c}}$ & 1.49 & 0.243 \\
Group B & $87.60 \pm 22.25^{\mathrm{a}}$ & $78.20 \pm 16.49^{\mathrm{b}}$ & $71.30 \pm 15.77^{\mathrm{c}}$ & 1.98 & 0.158 \\
\hline
\end{tabular}

a,b,cFor a particular variable, mode means with different superscripts are significantly $(\mathrm{P}<0.05)$ different. Mode means with same superscripts are not significantly $(\mathrm{P}<0.05)$ different.

Table 3: Summary of the one-way analysis of variance and Duncan's multiple range test post-hoc analysis of joint range of motion across treatment period. (Range of motion in degree).

\begin{tabular}{llllll}
\hline & $\begin{array}{l}\text { Baseline } \\
\mathbf{X} \pm \text { SD }\end{array}$ & $\begin{array}{l}\text { End of week 1 } \\
\mathbf{X} \pm \text { SD }\end{array}$ & $\begin{array}{l}\text { End of week 2 } \\
\mathbf{X} \pm \text { SD }\end{array}$ & F ratio & P value \\
\hline Group A & $75.70 \pm 28.01^{\mathrm{a}}$ & $80.00 \pm 29.41^{\mathrm{b}}$ & $91.70 \pm 33.46^{\mathrm{c}}$ & 0.74 & 0.49 \\
Group B & $80.55 \pm 29.65^{\mathrm{a}}$ & $84.20 \pm 30.63^{\mathrm{b}}$ & $91.20 \pm 32.62^{\mathrm{c}}$ & 0.31 & 0.74 \\
\hline
\end{tabular}

a,b,cFor a particular variable, mode means with different superscripts are significantly $(\mathrm{P}<0.05)$ different. Mode means with same superscripts are not significantly $(\mathrm{P}<0.05)$ different.

\section{DISCUSSION}

The result of the study revealed decrease in pain for both low level LASER therapy and pulsed ultrasound in the management of seconddegree contusion among sportsmen. The finding of this study is consistent with previous studies that indicated both LLLT and pulsed ultrasound therapy as equally effective pain relieving modalities (Prentice, 1986; Enwemeka, 1988). This support the observation by Buckwalter et al (2000), that the resultant effect in pain level is equal in the use of LLLT and pulsed ultrasound especially in acute injuries. Gur et al (1996) reported relief of pain in patients with sub-acute symptoms with only two sessions of LASER therapy, we found more significant reduction in pain at the end of the 2 weeks than the 1 st week for both modalities.

This study found that both modalities did not produce significant improvement in ROM or swelling over two weeks period. However, conflicting findings have been reported in some studies, Stratton et al (1984) opined that the reduction rate with the use of LLLT is much faster than the resolution of the oedema with the use of pulsed ultrasound. While Prentice (1986) and Stauber (1990), found no significant oedema resolution with both the LLLT and pulsed ultrasound in sport induced inflammation; Aoada et al (1989) found a ROM improvement of $56.3 \%$ using LLLT in a controlled study that involved chronic rheumatoid arthritic patients with severe joint affectation treated over a 2 year period.

\section{CONCLUSION}

It is concluded that both LLLT and pulsed ultrasound treatments can be used effectively for pain relief in second-degree contusion experienced by sportsmen. It is possible that natural progression may be responsible for the greater improvement over the weeks of treatment. It is hereby recommended that double blind, placebo-controlled, randomallocation studies involving larger population be carried out to ascertain the effect of natural progression in the treatment of pain resulting from sport injuries. 


\section{REFERENCES}

- Aoada K, Ytani Y, Sakawa A and Shimazu A (1989). Clinical Application Of Gaalas 830 Nm Diode Laser In Treatment Of Rheumatoid Arthritis. Research Abstracts Laser Therapy and Sports Injuries.

- Bjordal JM, Couppé C, Ljunggren E. (2001). Low Level Laser Therapy For Tendinopathy. Evidence of A Dose-Response Pattern. Physical Therapy Reviews; 6: 91-99.

- Buckwalter JA, Einhorn TA and Simon SR. (2000). Orthopaedic Basic Science: Biology and Biomechanics of the musculoskeletal system, 2nd edition. Resemonth, IL, American Academy of Orthopaedic Surgeon. 114-115.

- Cyriax J (1982). Textbook of Orthopaedic Medicine. Vol. 2

Diagnosis of Soft tissue lesions, 11th Edition, Baillieiere Tindall, London, 46-50.

- DeLee JC. Diez D, Stanitski CL. (1994). Orthopaedic Sport Medicine. Principle and practice. Philadelphia, WB Saunders, 786-789, 1106-1108.

- Dyson M and Pond JB. (1970). The effect of pulsed ultrasound on tissue regeneration. Physiotherapy: 56: 136-42.

- Enwemeka CS. (1988). Laser bio-stimulation of healing wounds. Specific effects and mechanism of action. Journal of Orthopaedic and Sport Physical Therapy, 9(10): 333-338.

- Gur A, Karakoc M, Nas K, Cevik R, Sarac J and Demir E. (1996). Journal of Clinical LASER. Physical Medicine and Rehabilitation, School of Physical Medicine, Dicle University, Diyarbakir, Turkey 14(4): 163-7.

- Huston M.A. (1990). Sport injuries: Recognition and management. Oxford medical publications. New York, 1 - 16; 36-49; 199-219.

- Keene J. (1985). Ligament and muscle tendon unit injuries. Orthopaedic and Sport Physical Therapy. CV Mosby. St Louis, 2: 63-71.
- Larson CM, Almekinders LC, Karas SG and Garrett WE. (2002). Evaluating and managing muscle contusions and myositis ossificans. The Physician and Sport Medicine. 30: 2.

- Logdberg-Anderssont M, Mutzell S, and Hazel A. (1997). Low Level Laser Therapy (LLLT) of Tendinitis and Myofascial Pains. A Randomized, Double-Blind, Controlled Study. Laser Therapy: 9: 79-86.

- Prentice WE. (1986). Therapeutic modalities in sport Medicine. Times. Mirror/Mosby college publishing, St Louis, Mo. 1-5.

- Rodgen MM and Cavanaugh PR. (1984). Glossary of Medicine and Sport injuries, 64: 84.

- Sanders RC. (1984). Clinical Sonography, a practical guide. First edition Boston, Little Brown and Company, 4-6.

- Sherk HH. (1990). Laser in orthopaedics 2nd edition. J.B. Lippincott company 17: 712-843.

- Stauber W. (1990). Repair model and specific tissues response in muscle injury in sport induced inflammation. American Academy of Orthopaedic Disease: 205-215.

- Stone DR. (1994). Sport injuries. Mechanisms, Prevention and treatment. Baltimore, Williams and Wilkins, 758-759.

- Stratton SA, Heckmann R and Francis RS. (1984). Therapeutic ultrasound, its effects on integrity of a non-penetrating wound. Journal of Orthopaedic and Sport Physical Therapy. 5: 278-281.

- Thomson A, Skinner A and Piercy J. (1991). Tidy's Physiotherapy. 12th edition. London. Butterworth / Heinemann.

- Wikipedia (2006). Wikipedia, The free Encyclopedia. wikipedia.org/wiki/Bruise. 08/09/06. 4:44p.m. 